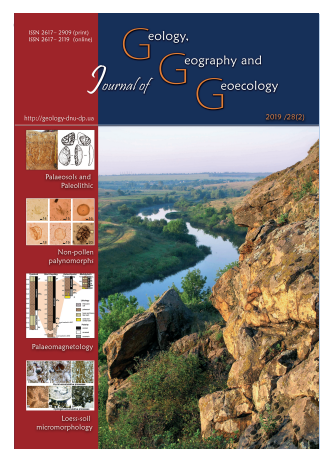

O.S. Bonchkovskyi

\section{Journal of Geology.} Geography and Geoecology

Journal home page: geology-dnu-dp.ua
ISSN 2617-2909 (print)

ISSN 2617-2119 (online)

Journ.Geol.Geograph.

Geology,

28(2), 230-240.

doi: $10.15421 / 111924$

\title{
Changes in pedogenic processes during Pryluky times (Late Pleistocene) in the central part of the Volyn Upland
}

\section{O.S. Bonchkovskyi}

Taras Shevchenko National University of Kyiv, Kyiv, Ukraine, e-mail: geobos2013@gmail.com.

Received: 06.05.2019

Received in revised form: 20.05 .2019

Accepted: 28.05.2019

Abstract. In the central part of the Volyn Upland, the Pryluky palaeosol unit have been studied in nine loess-soil sites (Boremel 1 - 3, Novyi Tik, Smykiv, Shybyn, Kolodezhi, Kovban, Novostav). Several sections were excavated along a slope in each studied site in order to reveal the palaeocatena and to study the most complete palaosol successions. The last were found in palaeorelief depressions, which were acting as sediment traps. The genetic interpretation of palaeosols was carried out on the basis on field macromorphological and analytical (micromorphology, grain-size analysis, content of humus and $\mathrm{CaCO}_{3}$ ) studies. In order to reconstruct the main features of palaeovegetation as an important factor of pedogenesis, pollen analysis of the palaeosols was carried out. It proved a good correspondence between a character of palaeovegetation and a palaeosol type. It has been shown that grain-size composition of the lower Prylyky soils strongly depends on that of parent rocks (Tyasmyn unit of hillwash sandy loam and Kaydaky unit of pedosediment).. The Chernozem-like polygenic soil is the most common within studied area. The lower part of soil has signs of podsolization (powder of $\mathrm{SiO}_{2}$, light color, low content of clay). The upper Pryluky soils are distorted by erosional and cryogenic processes (mainly by solifluction textures) that hampers the interpretation of diagenetic and original pedogenic processes. The abundant bioturbations in the subsoil (the largest number among the Late Plestocene soils), high content of humus, complex microaggregates, but leach in the $\mathrm{CaCO}_{3}$ have been established to Pryluky soil unit. The presence of relic pedogenic signs in the polygenetic soil, an assumption is made about the existence of several stages of its formation. The investigation of pedocomplexes confirm it. The study of well-developed pedocomplexes in sedimentation traps allows the allocation of those pedogenic phases during Pryluky times: $\mathrm{pl}_{1 \mathrm{~b} 1}$ - Podzolic, Cryptopodzolic, Albeluvisol, Albic Luvisol; $\mathrm{pl}_{1 \mathrm{~b} 2}-$ Luvic Chernozem, Chernic Chernozem and Cryptopodzolic,; $\mathrm{pl}_{1 \mathrm{c}}-$ Umbrisol and Cambic Luvisol; $\mathrm{pl}_{3 \mathrm{a}}-$ Luvic Cambisol; $\mathrm{pl}_{3 \mathrm{bl}}-$ Luvisol and Luvic Cambisol; $\mathrm{pl}_{3 \mathrm{~b} 2}-\mathrm{Mollic}$ and Luvic Cambisol.

Keywords: pedocomplex, pedogenetic phases, micromorphological features, pedosediment, palaeosol catena.

\section{Розвиток педогенних процесів впродовж прилуцького етапу у центральній частині Волинської височини}

\section{О.С. Бончковський}

Київський національний університет імені Тараса Шевченка, Київ, Україна. e-mail: geobos2013@gmail.com.

Анотація. У центральній частині Волинської височини педокомплекс прилуцького кліматоліту (верхній плейстоцен) вивчено у 9 лесово-грунтових розрізах (Новий Тік, Боремель 1 - 3, Смиків, Шибин, Колодежі, Ковбань, Новостав). Поховані грунти досліджено макроморфологічним і мікроморфологічним методами, виконано їхній гранулометричний аналіз, визначено вміст карбонатів і гумусу. Це дозволило інтерпретувати генетичні ознаки палеогрунтів та фар їхнього розвитку. 3 метою реконструкції природних умов формування давніх грунтів виконано палінологічний аналіз. Це дозволило виявити чітку кореляцію між типом рослинності і типом грунту. Показано, що супіщаний гранулометричний склад грунтів прилуцького педокомплексу у більшості розрізів обумовлений складом материнських порід (делювіальних супісків тясминського кліматоліту чи супіщаних педоседиментів кайдацького кліматоліту). Верхня частина прилуцького педокомплексу трансформована епігенетичними ерозійними і кріогенними процесами, зокрема соліфлюкцією. Встановлено, що на досліджуваній території прилуцький кліматоліт найчастіше представлений полігенетичними чорноземоподібними грунтами. У седиментаційних пастках простежено їхній перехід у грунтові світи потужністю понад 2 м. Дослідження грунтових світ дало змогу відтворити послідовність розвитку педогенезу впродовж прилуцького часу за такими фазами: $\mathrm{pl}_{\mathrm{lbl}}$ - лісові грунти (дерново-підзолисті, 
дерново-криптопідзолисті, дернові опідзолені, буро-підзолисті); $\mathrm{pl}_{\mathrm{lb2}}$ - лісостепові грунти (чорноземи опідзолені та вилугувані, дерново-криптопідзолисті); $\mathrm{pl}_{1 \mathrm{c}}$ - лісостепові грунти (дернові опідзолені та бурі лесивовані); $\mathrm{pl}_{3 \mathrm{a}}-$ лісостепові грунти (дерново-бурі грунти); $\mathrm{pl}_{3 \mathrm{bl}}$ - лісові грунти (бурі лесивовані і дерново-бурі опідзолені); $\mathrm{pl}_{3 \mathrm{~b} 2}$ - лісостепові грунти (дерново-бурі і дернові). За прошарками лесоподібного і делювіального матеріалу між грунтами та за наявністю кріогенних структур вдається виявити декілька стадій припинення або ж значного послаблення педогенних процесів.

Ключові слова: грунтова світа, стадія та фаза педогенезу, мікроморфологічна будова, педоседимент, грунтова катена.

Introduction. The Pryluky soil unit is one of the most reliable stratigraphic markers within the Upper Pleistocene in Ukraine (Veklitch, 1982; Sirenko, Turlo, 1986), including the Volyn Upland. The correlation of the upper boundary of the Pryluky unit with the transition between MIS 5 and MIS 4 is firmly established in Ukraine, but different views exist on the correlation of the lower soil of Pryluky unit with the global marine isotopic oxygen record. It has been correlated either with substage 5e (Veklitch et al., 1993; Gozhik et al., 2000; Lindner et al., 2002, 2006; Bogutskyi et al., 2012) or with the substage 5c (Rousseau et al., 2001; Gerasimenko, 2004; Matviishina et al, 2010; Haesaerts et al., 2016). In western Ukraine, the Pryluky unit corresponds, in the author's opinion, to the upper part of the Horokhiv pedocomplex of the regional stratigraphic framework of A. Bogutskyi (Bogutskyi, 1986). In recent years, the upper part of the Horokhiv pedocomplex has been considered as a separate Kolodiiv soil unit, which in the stratigraphically complete sections is represented by three soils (Lanczont, Bogutskyi, 2007; Bogutskyi et al., 2012). Two Kolodiiv soils have been studied in the Rivne and Dubno sections of the Volyn Upland (Bogutskyi, Voloshyn, 2008; Bogutskyi, Voloshyn, 2011), though in the majority of the sections of this area (Korshiv, Horokhiv, Novovolynsk, Boyanychi, Peremyslovychi, Zdolbuniv, and Torchyn) one chernozem-like soil is distinguished at this level (Tsatskin, 1980; Morozova, 1981; Bogutskyi, 1986). The description of palaeopedological and engineergeological features of the Horokhiv soils has been presented in Bogutskyi, and Voloshyn (2008, 2010, 2011). Palaeopedological and micromorphological studies of the Horokhiv soils in their palaeocatenas were carried out by A. Tsatskin (1980) and T. Morozova (1982). Palynological characteristics of the Kolodiiv soil were presented by Artyushenko et al., (1982) and Bezusko et al., (2011).

Materials and methods. In the central part of the Volyn Upland, the Pryluky pedocomplex has been studied at nine loess-soil sites (Boremel 1 - 3, Smykiv, Novyi Tik, Shybyn, Novostav, Kolodezhi, and Kovban) (Fig. 1). In the majority of the sites, the Pryluky soil unit is represented by a polygenic chernozem-like soil with well-expressed mollic epipedon (0.3-0.7 $\mathrm{m}$ thick). The main aim of this research was to study the palaeosol catena, in order to reveal the lateral replacement of polygenic soils by well-developed pedocomplexes in the palaeorelief depressions (sediment traps). Thus, a series of excavated profiles have been studied at each site following the elements of modern and buried relief.

In the palaeodepressions, several soils of the Pryluky pedocomplex (up to five at the Novostav site) were revealed. In the field, diagnostic macromorphological features of paleosols, including their genetic profiles, were studied, as well as diagenetic and relic features of pedogenesis. The last produce 'noise' in the original palaeopedological information. Thus, the identification of relic, syngenetic or diagenetic elementary soil processes in the palaeosol is a most actual problem when interpreting their primary genetic types.

The genetic interpretation of soil types was also based on analytical studies: micromorphological, grain-size analysis, determination of humus content and $\mathrm{CaCO}_{3}$. The grain-size analyses of Pryluky soils from the Boremel-1, Boremel-2, Novyi Tik, Novostav, and Kolodezhi sections has been carried out by the Kachynskyi'method; content of humus was determined by Turin's method (Fig. 2; 3). Palaeopedological interpretation of results has been done following Veklitch et al. (1979). Micromorphological analysis of the soils from Novyi Tik has been carried out using the methodology of Parfenova, Yarilova (1977), Matviishyna (1982), Gerasimova et al. (1992), Gagarina (2004), Karmazinenko (2010), and Doroshkevych (2018). In addition, pollen study of the Novyi Tik and Kolodezhi samples was done to reveal the correspondence between paleovegetation and palaeosoil formation. The use of the two methodologies is beneficial for identification of short-period phases in the development of pedogenic processes.

Results. On the basis of the described studies, those phases in the development of pedogenic processes during the Pryluky times have been identified. During phase $\mathbf{p l}_{1 \mathrm{~b} 1}$, several genetic types of forest soil were formed, controlled by differences in their parent rocks. Podzols formed on sands (Fig 4; 7b); Albeluvisols (Fig. 5c) and Cryptopodzols (Fig. 7c) developed on loess-like sandy loams; and Albic Luvisols (Fig. 5a) formed on the sandy material of 


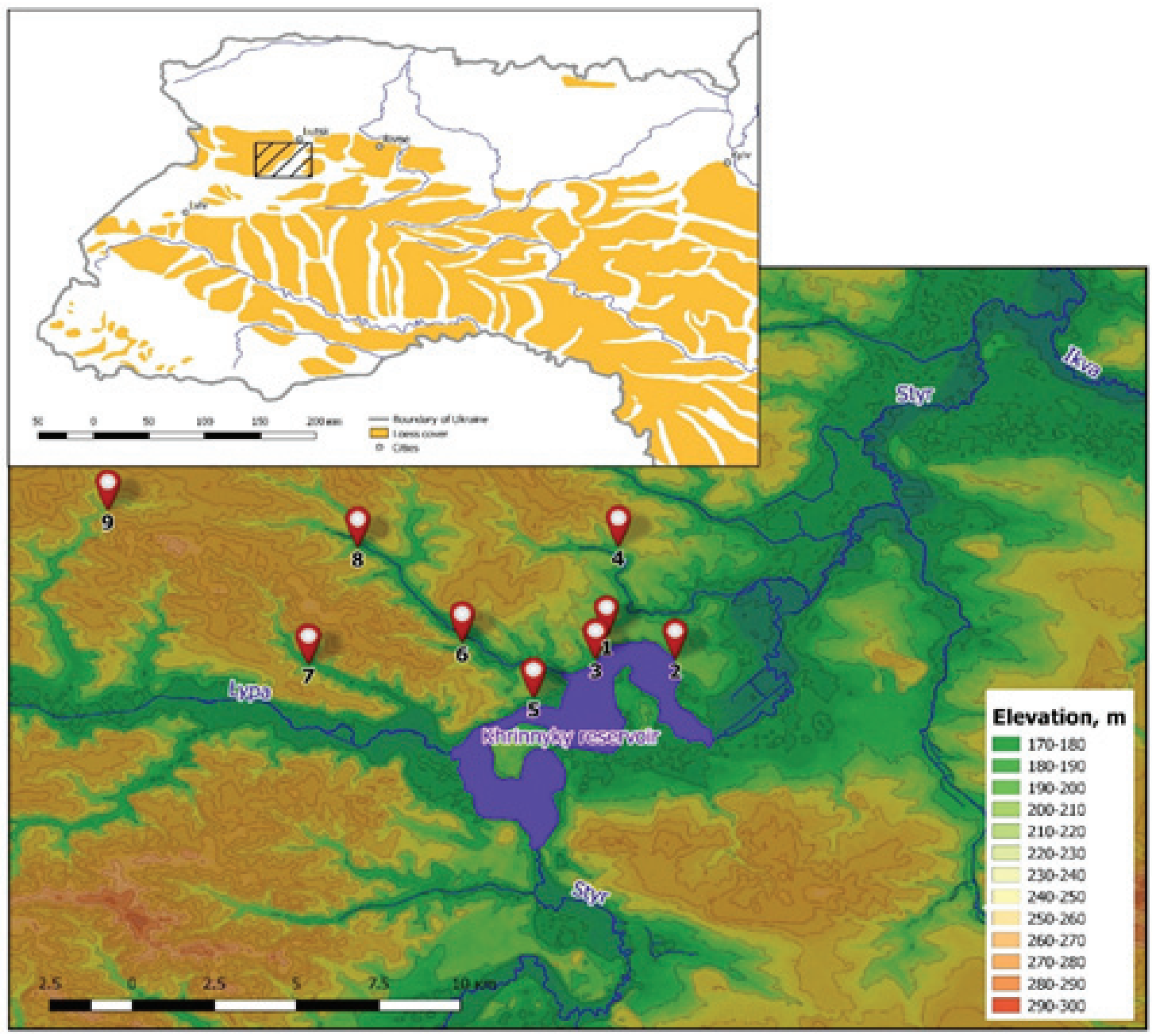

Fig. 1. Location of the sections studied: 1- Boremel-1; 2 - Boremel-2; 3 - Boremel-3; 4 - Novyi Tik; 5- Shybyn; 6 - Smykiv; 7 - Novostav; 8 - Kolodezhi; 9 - Kovban.

the Kaydaky unit. Frequently, the lower Pryluky soils overlying the Kaydaky unit form a polygenetic pedocomplex, consisting of forest soils.

Pryluky unit podzols occur on colluvial sands and sandy loam (at Novyi Tik and Kovban) or on Kaydaky sandy material in relief depressions (at Boremel). The profile of podzols (up to $0.5-0.7 \mathrm{~m}$ thick) consists of AEL, E, and BCf genetic horizons (Fig. $4 ; 7 \mathrm{~b}$ ). The AEL horizon, with a low content of humus $(0.11 \%)$, form, in places, the lower podzoled part of the overlying soil $\mathbf{p l}_{1 \mathrm{~b} 2}$. The E horizon (up to 0.1-0.25 m thick) is composed by a whitish-grey sand or sandy loam (sand fraction up to $82 \%$ at Kovban), with an initial platy structure and pseudofibres. In thin sections of these soils, the material is depleted in plasma (Fig. 6a). Skelsepic iron-humus-clay plasmic fabrics are observed at the contacts of sand grains. Simple iron-humus-clay cutans are revealed in the voids. In places, iron-manganese micro-ortsteins occur. At Kovban, the E horizon overlies the Tyasmyn unit, composed by sands, and, thus, it is better expressed than in other sections. The BCf horizon overlays sands of the Tyasmyn unit or the Kaydaky pedocomplex. In the first case, it is represented by light-brown sandy loam, without soil structure, but with well-expressed pseudofibres. In thin sections, clear evidence of translocation processes are observed (a lot of iron and iron-clay coatings around rounded quartz grains, which are merged together. and forming 'bridges' (Fig. 6b).

Cryptopodzols (up to 0.3-0.5 in thickness) were revealed at Novyi Tik, Boremel-1, Smykiv, and Kolodezhi (Fig. 7c), where they are represented by sandy loams (sand content up to $65 \%$ ), with a low incidence of humus $(0.35 \%$ in the AEL horizon, $0.2 \%$ in the B horizon), and a downward increase in the clay fraction (from $12 \%$ up to $21 \%$ ). The micromorphological fabrics of the $\mathrm{B}$ horizon have both depletion zones and zones of laminated ironclay and humus-iron-clay cutans with the signs of their destruction. Traces of mobility of dust-plasma coating are observed in large pore spaces, which is reliable evidence of intense lessivage. There are a lot of iron-manganese pedofeatures in this horizon (micro-ortsteins, diffusion rings, stains and manganese coatings in the voids). Cutans and pedofeatures are 


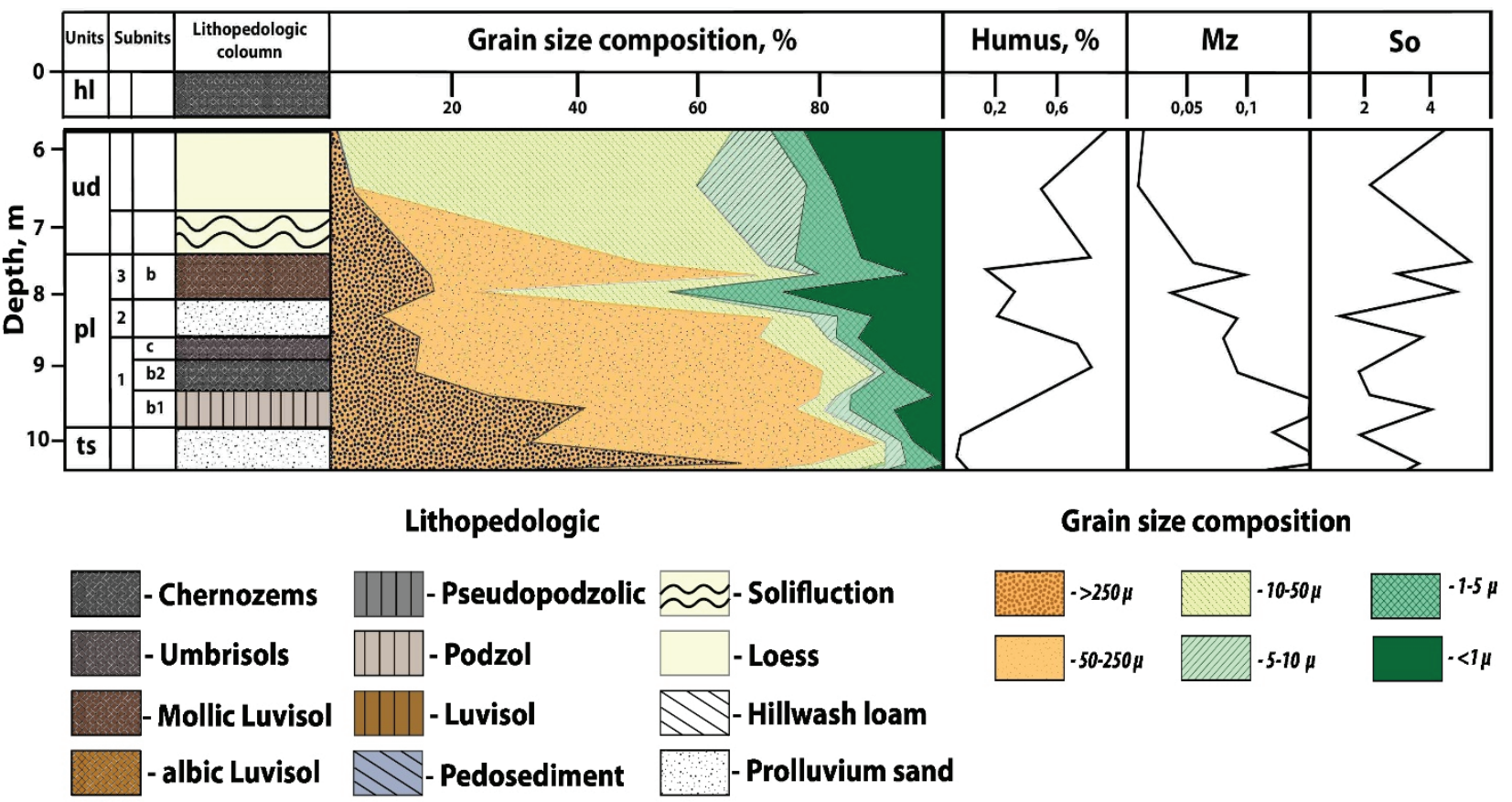

Fig. 2. Lithopedological features of the Pryluky unit in the Novyi Tik section.

characterized by mud-cracks, indicating alternating the Eh horizon to $28 \%$ in the BELt horizon). The wet and dry periods. soil profile consists of AEL, Eh, and BELt horizons.

An Albic Luvisol (up to 0.5-0.6 $\mathrm{m}$ in thickness) The AEL horizon is greyish-brown, with single was revealed at Novostav (Fig. 5a), where it is a pseudofibres. The BEL horizon comprises cemented sandy loam (content of sand up to 52-70\%), with a sands, with loose whitish sand lenses.

significant downward increase in clay (from $4 \%$ in On the basis of the paleopedological data, it is

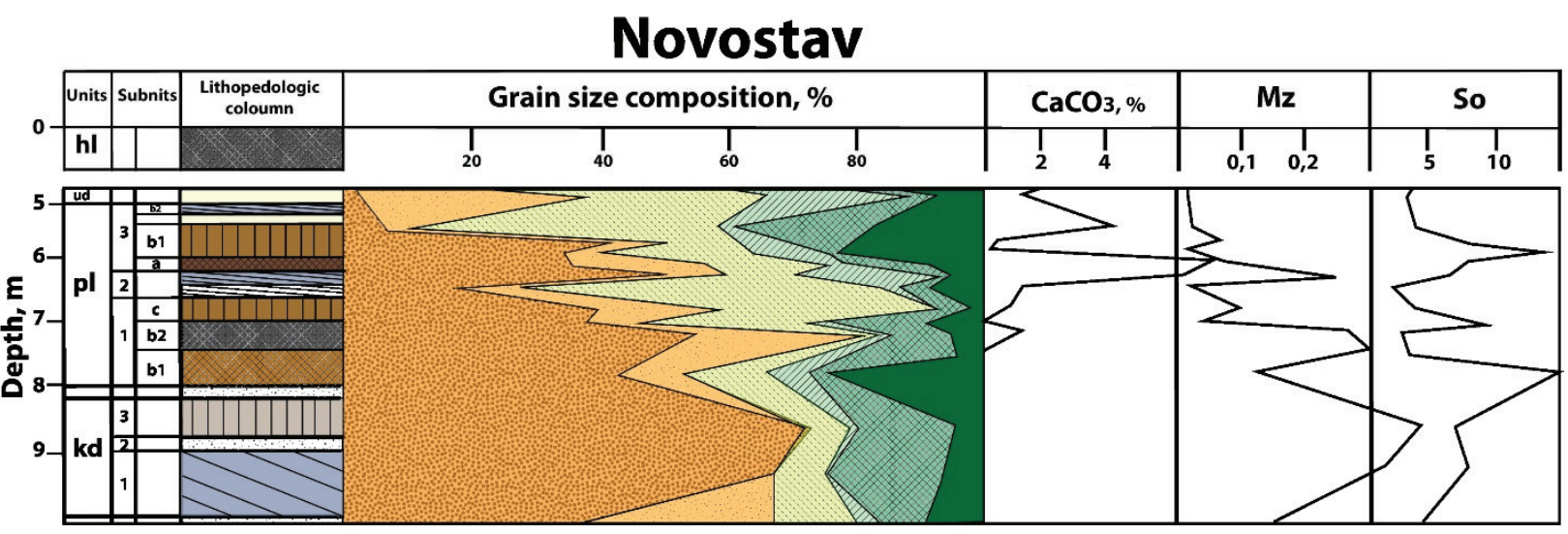

\section{Kolodezhi}

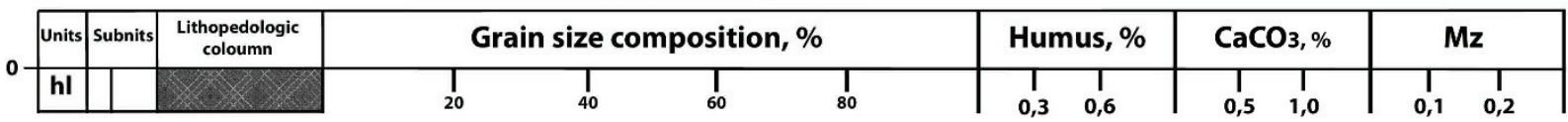

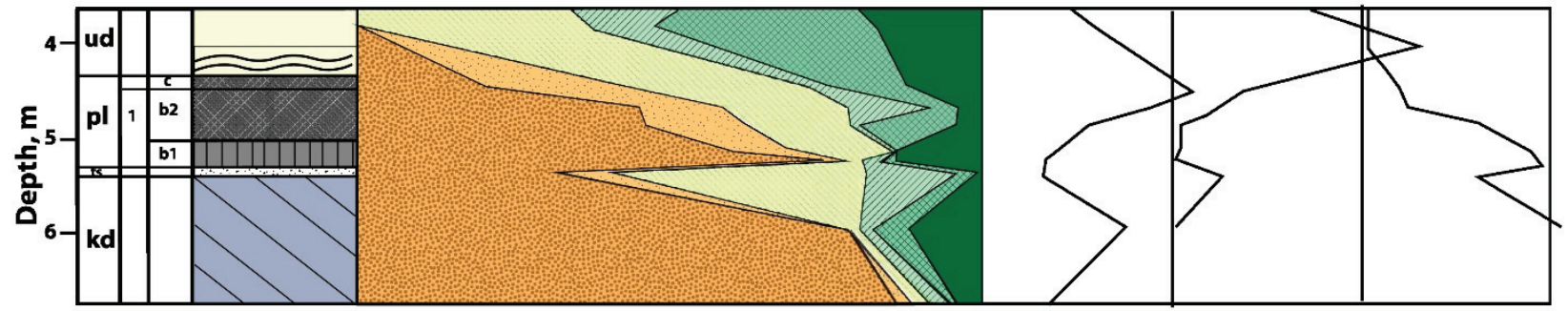

Fig. 3. Lithopedological features of the Pryluky unit in the Novostav and Kolodezhi sections (for legend see in Fig. 2). 

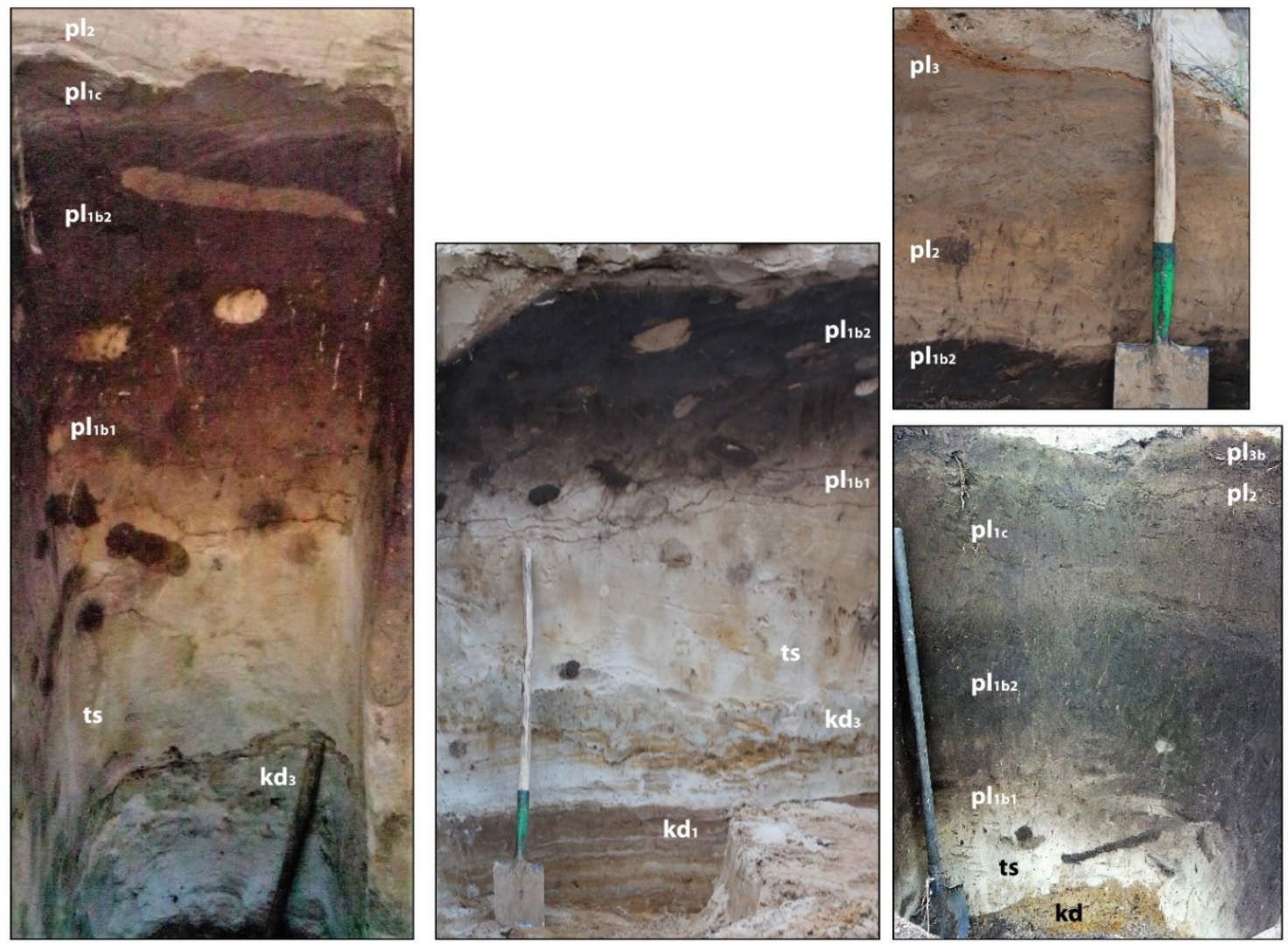

Fig. 4. The Pryluky pedocomplex in the Novyi Tik section.

suggested that the early optimum of Pryluky times $\left(\mathbf{p l}_{1 \mathrm{bl}}\right)$ had a humid climate, which lead to intense development of podzolisation in the soils. Processes of lessivage and leaching were mainly controlled by sandy material of the soil's parent rocks. The process of humus accumulation was rather weak: humus components were destroyed by aggressive organic acids which appeared as a result of podzolisation, or they were infiltrated as a result of lessivage. These soil properties indicate a wet temperate climate during the $\mathbf{p l} \mathbf{l}_{1 b 1}$ phase. The pollen analysis of the soils of the early climatic optimum shows a rather high content of tree pollen $(40.1 \%)$, with the predominance of the boreal taxa Pinus sylvestris and Betula sp. However, pollen of thermophiles (Carpinus and Quercus) is present in small percentages. Typical indicators of humid environments (pollen of Salix, Alnus, and Humulus), as well as a high percentages of spores (28.5\%) have also been detected. The climate was wet and relatively warm (subboreal), apparently this was the climatic optimum of the Pryluky time. The forest soils and the similar forest palynospectra in the lower soils of the Pryluky unit have been described in other areas of Ukraine (Sirenko, Turlo, 1986; Bolikhovskaya, 1995; Gerasimenko, 2004, 2006; Lanczont, Boguckyj, 2007; Matviishyna et al., 2010 and others).

The formation of Chernozem-like soils and, thus, the intensification of humus accumulation, occurred during the next phase, $\mathbf{p l}_{1 \mathrm{~b} 2}$. The pollen data obtained from the $\mathrm{A}$ and $\mathrm{AB}$ soil horizons an increase in pollen percentages of xerophytes, particularly Chenopodiaceae (up to 5\%), Ephedra (up to 5-8\%) and Poaceae (up to 20\%) is the evidence of aridification the end of the $\mathbf{p l}_{1 \mathrm{~b} 2}$ phase. Mesophytic (Poaceas Herbetum mixtum) steppes spread then.

During the $\mathbf{p l}_{1 \mathrm{~b} 2}$ phase, the soil cover was more homogeneous than before, as the dependence of soils on parent material was not as pronounced as during the early optimum. Although, such dependence was still present. Cryptopodzols were formed on a sandy loam substrate (at Kovban and Novyi Tik) (Fig. 4), Luvic Chernozem and Chernozem-like soils developed on the silt sandy-loam and silty-loam substrates, at Novyi Tik (Fig.4), Boremel (Fig. 7a), Smykiv (Fig. 5c), Kolodezhi (Fig. 7c) and Novostav (Fig. 5a), and chernic Chernozems on the silty loam substrates (at Novyi Tik and Korshiv). At Shybyn mollic Fluvisols developed on alluvial sands. The stratigraphic break on the overlying soil has led to the deformation of soils by solifluction processes, even on gentle slopes $\left(2-3^{\circ}\right)$, and the soils were disturbed by ground-wedges during Uday times.

Cryptopodzolic soils (up to $0.5-0.6 \mathrm{~m}$ in thickness) show noticeable signs of podzolisation in the upper part of their profiles, but there is no 


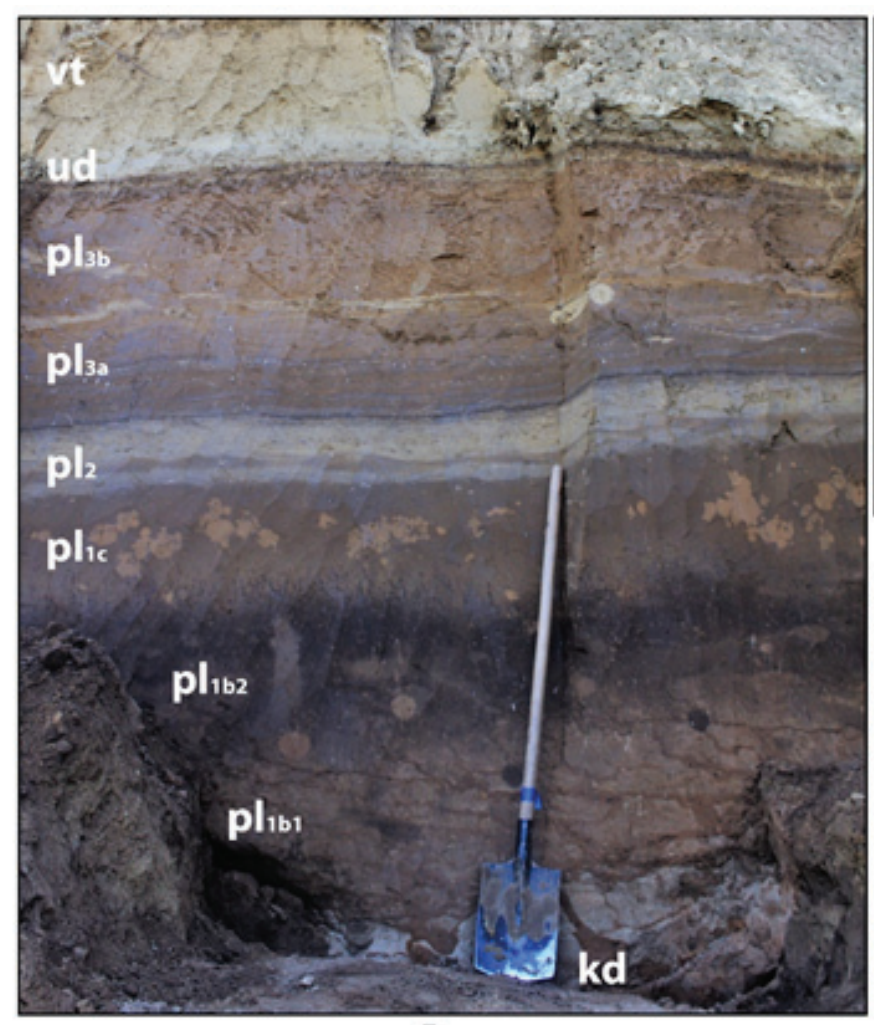

A

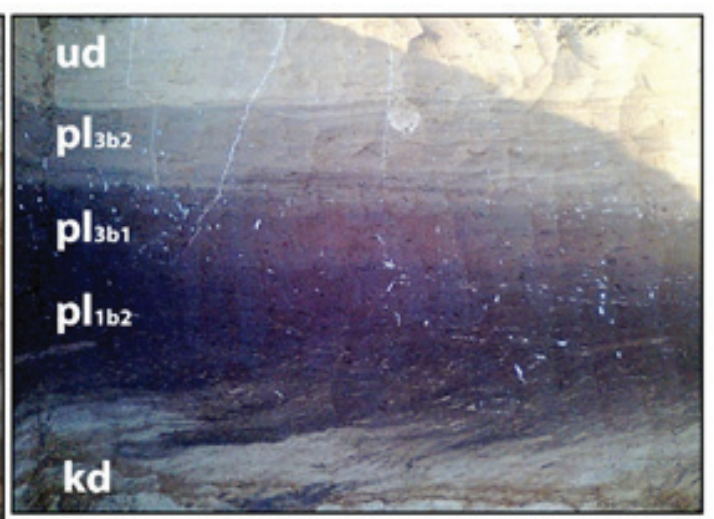

B

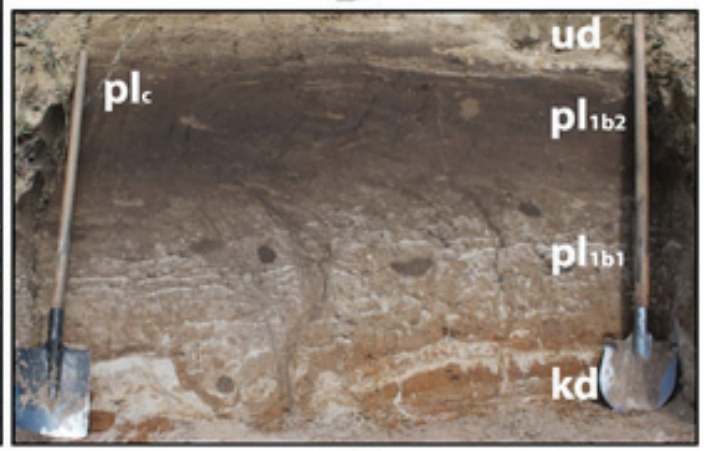

C

Fig. 5. The Pryluky pedocomplex in the Novostav (A), Smykiv (B) and Kovban (C) sections.

independent E horizon. Podzolisation and lessivage was mainly due to the sandy grain-size composition of the parent material. The soil is characterized by relatively low content of humus in the AEL horizon $(0.46 \%)$, an increasing in the clay fraction downwards (from $17 \%$ to $27 \%$ ), and the presence of a weak blocky structure in the $\mathrm{AB}$ horizon. Furthermore, numerous bioturbations are seen in the subsoil.

The micromorphological structure of the soil is a reflection of contemporaneous processes, such as podzolization and humus accumulation. In the AEL horizon, there are alternations of depleted plasma zones and layers enriched in clay. There is a prevalence of the humus mull that aggregated into rounded biogenic aggregates (Fig. 6c). The residues of organic matter also took place. Translocation processes in the $\mathrm{AB}$ horizon are identified by simple large iron-manganese fluid-like cutans (Fig. 6d), humus-clay hipocutans and quasicutans.

Luvic Chernozem and Chernozem-like soils were formed on silty sandy loam and silty loam substrates. Soils (up to 0.3-0.7 $\mathrm{m}$ in thickness) have a low degree of podzolisation: with weakly pronounced powdery of $\mathrm{SiO}_{2}$, which is visible only in the upper part of profiles. The redistribution of silt content down the sequence is almost not observed. The content of humus in soils increasing to $1 \%$. There are single secondary carbonates in the forms of pseudomorphs of roots. In places, carbonates emphasize the blocky post-cryogenic textures. In the subsoil, a large number of bioturbations are located.

There are no such bioturbations in any of the Late Pleistocene soils of the Volyn Upland. The A horizon has a spongy microstructure with complex microaggregates produced by network of channellike and aggregates fill the voids (Fig. 6e). The siltyhumus plasm is isotropic, but simple laminated ironmanganese cutans and clay coats in the $\mathrm{AB}$ horizon also formed. In the Ae horizon, there are zones depleted in plasm. Iron-manganese causes mottles and small stains, and less micro-ortsteins occur within profile. Inside fissures in quartz and feldspar grains iron oxides are located, which indicate processes of chemical weathering.

Chernic Chernozems (up to 0.4-0.6 m thick) were formed on silty loam parent materials and, within the studied area, they are the most similar to modern Chernozems. The soils almost lack signs of podzolisation, having a weak granular-crumb structure. Humus content is relatively high (up to $0.66 \%$ ) with domination of humic acids over fulvic acids (HAs / FAs $=1.1-1.8$ ) (Tsatskin, 1980). The soil fabric is strongly aggregated. There are dominant simple rounded ooid-like microaggregates (Fig. 6f). Such types of microaggregates, as well as bent fabrics, platy microstructure and networks of fissures (mud- 


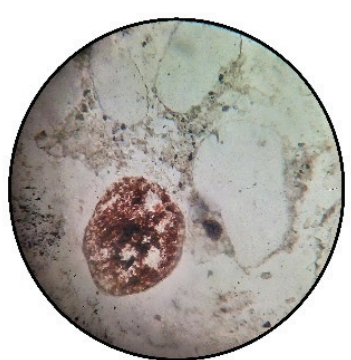

A

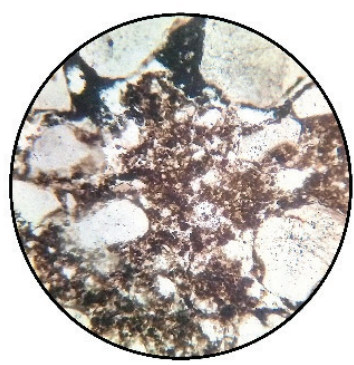

$\mathbf{E}$
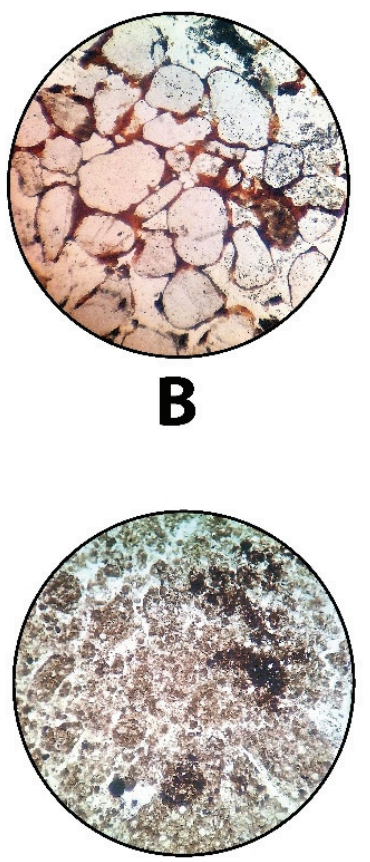

$\mathbf{F}$
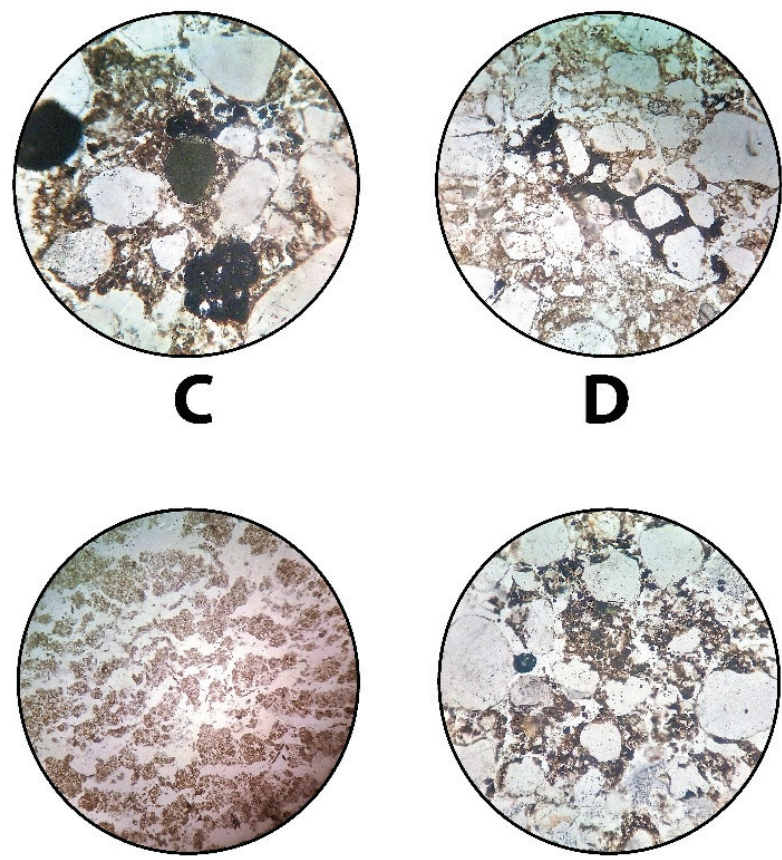

G

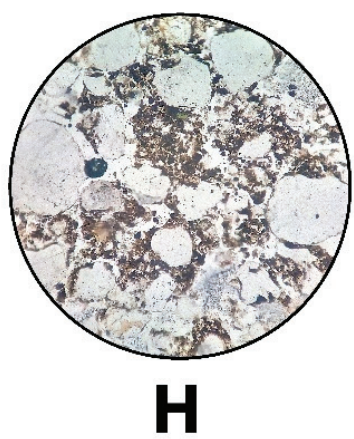

Fig 6. Micromorphological composition of the Pryluky soils in the Novyi Tik section: A - clean quartz grains (a result of podzolisation) and iron-manganese micro-ortstein in the $\mathrm{E}$ horizon of the $\mathbf{p} \mathbf{l}_{\mathbf{1 b 1}}$ Podzol complex organic-mineral microaggregates between sand grains and manganese pedofeatures in the Ae horizon of the Cryptopodzolic soil $\mathbf{~ p l}_{\mathbf{1 b 2}}$ (PPLx70); D - iron-manganese cutans in channel-like pores in the BCh horizon of the Cryptopodzolic soil pl1b2 (PPLx40); $\mathbf{E}$ - complex biogenic microaggregates in the Ae horizon of the luvic Chernozem $\mathbf{~ p l}_{1 \mathbf{b 2}}$ (PPLx70); $\mathbf{F}$ - ooidlike mineral-organic microaggregates and diagenetic iron-manganese impregnations in the A horizon of the Chernic Chernozem $\mathbf{p l}_{\mathbf{1 b 2}}$ (PPLx 40); $\mathbf{G}$ - bent fabric and platy microstructure in the A horizon of the luvic Chernozem $\mathbf{~ p l}_{\mathbf{l b 2}_{2}}$ - the result of cryogenic processes (PPLx40); $\mathbf{H}$ - depletion in clay material in the A1 horizon of the Luvic Cambisol as a result of podzolisation processes (PPLX40).

cracks or cryogenic cracks) were caused by epigenetic cryogenesis (Fig. 6g). In the soil, there is much ironmanganese pedofeatures such as micro-ortsteins, coats, stains and nodules. Some pedofeatures have been disturbed by dehydration cracks.

In some sections (Boremel, Novyi Tik, and Novostov) it is possible to detect the initial soils of the final phase of $\mathbf{p l}_{1 \mathrm{c}}$ (Fig. 4; 5a; 7a), which is separated from the soils of $\mathbf{p l}_{1 \mathrm{~b} 2}$ by a loess streak, as well as small frost fissures and mud-cracks. At Novyi Tik and Boremel, Umbrisols (up to 0.2-0.4 $\mathrm{m}$ in thickness) occur, with a relatively high content of humus $(0.41 \%)$, a weak powder of $\mathrm{SiO}_{2}$ and with numerous worm infilled worm burrows and ochre spots of ferrugination. At Boremel, there is a small quantity are floury secondary carbonates in the upper part of the profile. The soil has a micromorphological structure with greyish-brown isotropic humus-clay aggregated plasm and a vosepic plasmic fabric with iron and manganese domains. The aggregates are divided by an intricate network of mud-cracks and rounded pores. Quartz grains have thin humus-clay coatings around them. Residues of the organic matter also occur. The depletion of plasm material within isolated zones is an indicator of weak processes of podzolization.

Following palynological data obtained from $\mathbf{p l}_{1 \mathrm{c}}$ Umrisol in the Novyi Tik section, the mesophytic boreal steppe can be reconstructed. In the palynospectra, the incidence of pollen of xerophytic Ephedra (5\%) and hydrophytic Cyperaceae (32.5\%) is relatively high. Among tree species, there is a small amount of pollen of Alnus sp. and Pinus sylvestris.

In the Novostav section (Fig. 5a), there is a cambic Luvisol (up to $0.4 \mathrm{~m}$ thick), with a sandy loam composition (content of sand fraction is $52-55 \%$ ), and a slight increase in the clay fraction down the profile (from 3\% in the Ae horizon to $11 \%$ in the B horizon). The soil has a brown color, is leached (only secondary carbonates present), with a large number of worm holes and a weak powder of $\mathrm{SiO}_{2}$. There are pale (light-brown) spots of a chimeric form of obscure origin, which in places reach $0.3 \mathrm{~m}$ in thickness and the same in width, forming separate isolated spots 

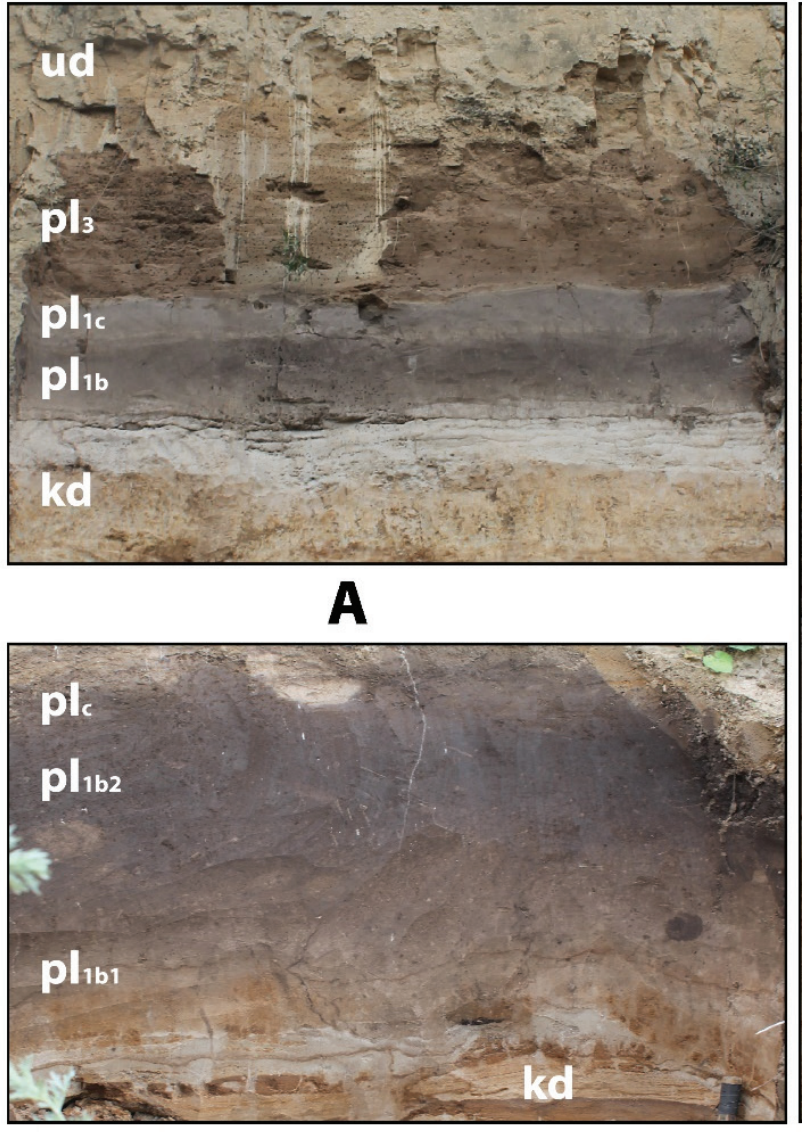

C

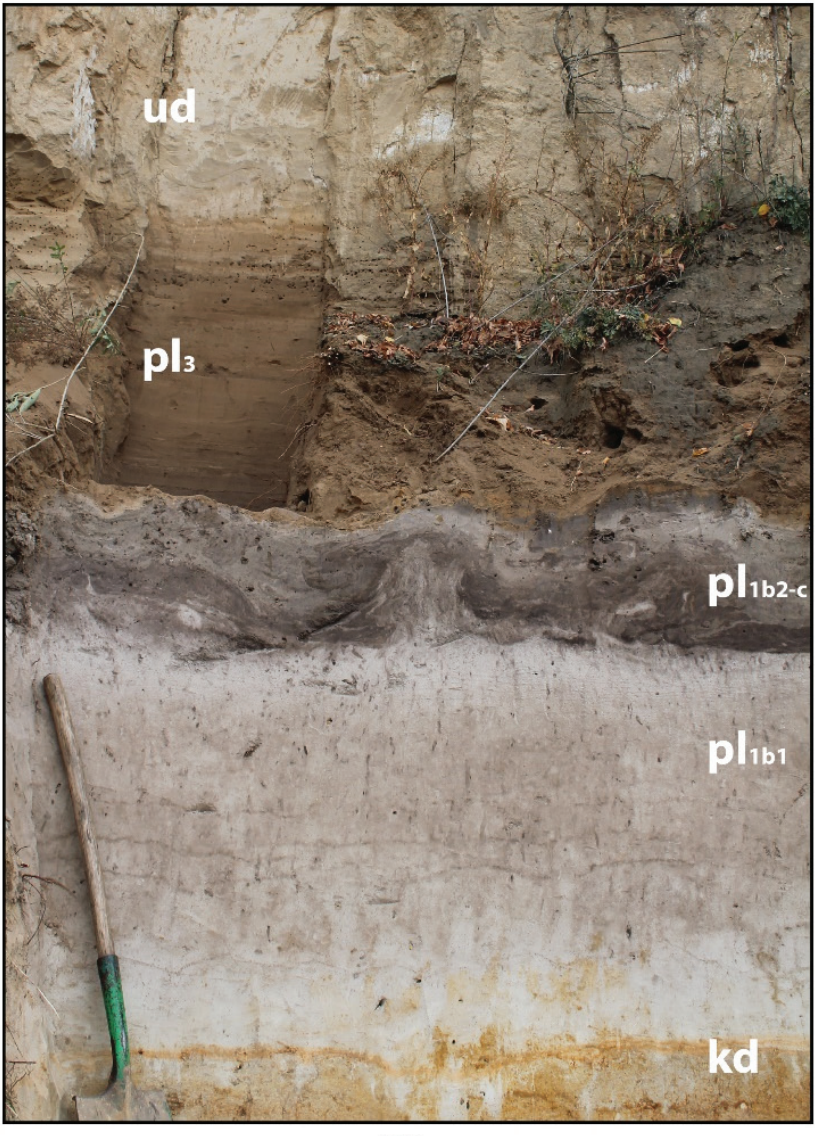

B

Fig. 7. Pryluky pedocomplex in the Boremel-2 (A, B) and Kolodezhi (C) sections.

or clusters (Fig. 5a). In some spots there are tiny injections of humus that creates 'bridges' inside the spots. The genesis of the spots is unclear so far. Perhaps they were the result of chemical destruction of pedofeatures, which were subsequently substituted by mineral material. Single small spots in the upper part of the Pryluky pedocomplex are also seen at Kovban, Novyi Tik and Smykiv. Similar features are known elsewhere in Ukraine (Gerasimenko, 2010).

The thin (up to $0.2 \mathrm{~m}$ thick) layer of non-soil material (loess, loess-like and hillwash loam) and a level with cryogenic features (solifluction, ground wedges and frost fissures) allow one to reconstruct a period of cold climate $\left(\mathbf{p l}_{2}\right)$ within Pryluky times (Fig. $4 ; 5 \mathrm{a} ; 5 \mathrm{~b}$ ).

The soils of $\mathbf{p l}_{3}$ have mostly been (partially or completely) denuded in the studied area (at Kovban, Kolodezhi, and Korshiv). It is difficult to trace a clear stratigraphic break, because soils and deposits were deformed by solifluction processes during Uday cold times. The presence of a denuded B horizon in the upper part of soil $\mathbf{p l}_{1}$, with increasing of clay content up the profile, as well as a residual blocky structure, allow one to interpret the former presence of soil $\mathbf{p l}_{3}$. At Boremel, Novyi Tik and Novostav, pedosediments of a Luvisol were revealed above the loess streak (Fig. $7 \mathrm{a} ; 7 \mathrm{~b})$. In the area of the Volyn' Upland, Luvisols $\mathbf{~ p l}_{3}$ has been described in the Dubno section (Bogutskyi, Voloshyn, 2011), and correlated to the Kolodiiv-1 soil of the regional stratigraphic scheme (Lanczont, Bogutskyj, 2007).

At Boremel-3, the Luvisol $\mathbf{p l}_{3}$ (up to $0.7 \mathrm{~m}$ thick) occurs, with a dark A horizon and a brown unstructured Bmt horizon. At Novyi Tik (Fig. 4), an Upper Pryluky subunit consists of a lower luvic Cambisol $\left(\mathbf{p l}_{3 \mathrm{b1}}\right)$ overlain by prolluvial sands. Above the last is pedosediment of a luvic Cambisol ( $\mathbf{p l}_{3 \mathrm{~b} 2}$ ) occurs. The Luvic Cambisol ( $\mathbf{p l}_{3 \mathrm{~b}}$ ) (up to $0.3 \mathrm{~m}$ thick) includes $\mathrm{Ae}$ and $\mathrm{AB}$ horizons. The soil, in microstructure, has brownish-grey, isotropic, well-aggregated clayhumus plasm with domains of the vosepic, mosepic and insepic plasmic fabrics. There are depleted in the plasm zones as a result of podsolization (Fig, $6 \mathrm{~h}$ ). In the AB horizon, simple, large iron-manganese cutans, as well as iron-manganese coatings and stains, appear.

Pedosediment of luvic Cambisol $\mathbf{p l}_{3 \mathrm{~b} 2}$ (up to $0.7 \mathrm{~m}$ thick) show signs of differentiation in the Ae, $\mathrm{ABg}_{\mathrm{ca}}$, and $\mathrm{BCg}$ horizons (Fig. 4). It is characterized by a relatively high humus content in the Ae horizon $(0.43 \%)$ as well as a high content of clay in the $\mathrm{ABg}_{\text {ca }}$ 
horizon, and secondary intensive gleying. There are a large number of secondary carbonate nodules. At the lower boundary of the soil, a resistant streak of ferrugination (up to $4 \mathrm{~cm}$ in thickness) occurs. It can be suggested that it fixes the position of the lower boundary of the active layer during in the Uday cryogenesis. Furthermore, the cryogenic metamorphism of the pedosediment was followed by development of a weak platy structure, a blocky postcryogenic texture, solifluction and gelifluction.

A similar $\mathbf{p l}_{3}$ pedocomplex is revealed in the Smykiv section (Fig. 5b). A lower soil ( $\mathbf{p l}_{3 \mathrm{~b} 1}$ ) is a loamy luvic Cambisol (up to $0.3 \mathrm{~m}$ thick) with abundant manganese pedofeatures. The upper soil $\left(\mathbf{p l}_{3 \mathrm{~b} 2}\right)$ is a loamy mollic Cambisol (up to $0.3 \mathrm{~m}$ thick), with abundant secondary carbonates. It is differentiated into $\mathrm{A}$ and $\mathrm{BC}$ horizons. Down of the slope, the soil is strongly disturbed by solifluction.

At Novostav, a pedocomplex with three soils is revealed (Fig. 5a). However, soils of the beginning $\left(\mathbf{p l}_{3 \mathrm{a}}\right)$ and the final $\left(\mathbf{p l}_{3 \mathrm{~b} 2}\right)$ phases have the features of pedosediment of the mollic Cambisols. The pedosediment of the mollic Cambisol $\left(\mathbf{p l}_{3 \mathrm{a}}\right)$ has a sandy-loam grain-size, with the sand fraction reaching 47.5\%. In the subsoil, the Bca horizon has a content of $\mathrm{CaCO}_{3}$, which reaches $7.3 \%$. The Luvisol $\mathbf{p l}_{3 \mathrm{~b} 1}$ (up to $0.4 \mathrm{~m}$ thick) is a sandy clay loam, with increasing content of clay down the sequence (from $20 \%$ in the Ae horizon to $29 \%$ in the Bmt horizon). The soil is unstructured, partially gleyed, with abundant manganese pedofeatures and single secondary carbonate nodules (the content of $\mathrm{CaCO}_{3}$ is 0.27 $0.44 \%$ ). In the direction of slope, the soil gradually turns/grades into pedosediment. A weak layer of loess-like loam (up to $0.2 \mathrm{~m}$ thick) lies above, under an incipient mollic Cambisol $\left(\mathbf{p l}_{3 \mathrm{~b} 2}\right)$. The last has dark-grey color, a silty loam grain-size and secondary carbonates localized as soft white spots (content of $\mathrm{CaCO}_{3}$ is $4.03 \%$ ). The top of the soil is affected by mud-cracks and frost fissures.

From the correlation of the $\mathbf{p l}_{3}$ soil / pedocomplex in different excavations it may to inferred that it comprises three phases of pedogenesis. The soil of phase $\mathbf{p l}_{3 \mathrm{a}}$ is represented by a mollic Cambisol. During the $\mathbf{p l}_{3 \mathrm{bl}}$ phase, a Luvisol and a luvic Cambisol were formed. At Novyi Tik, a luvic Cambisol is characterized by relatively a large humus content and the presence of complicated microaggregates. Perhaps this is due to the imposition of the soil of the early optimum $\left(\mathbf{p l}_{3 \mathrm{bl}}\right)$ on the underlying incipient soil $\left(\mathbf{p l}_{3 \mathrm{a}}\right)$. During the late optimum $\left(\mathbf{p l}_{3 \mathrm{~b} 2}\right)$ there was climatic aridification, which caused the formation of incipient luvic and mollic Cambisols.
The intense cryogenesis during the Uday times led to significant soil disturbance, the movement of soil material through solifluction, and significant cryogenic pedometamorphism. For instance, at Shybyn a mollic Gleysol $\mathbf{p l}_{3}$ is intensively disturbed by spot-medallions. Post-thixotropy textures, fairly signs of frost-sorting of the material (with the sand fraction located to the periphery of the polygons), gelifluction and cryoturbation are all detected in the soil. Obviously, the strong gleying of the soil and lack of genetic horizons are secondary phenomena, caused by cryogenic processes. Thus, the primary soil was radically transformed by cryogenesis to a Gleysol, and is now impossible to reconstruct. Only in places is there a thick A horizon that is barely noticeable.

\section{Conclusions:}

1. The Pryluky unit is frequenty represented by a polygenetic chernozem-like soil, but in favourable sedimentation conditions, it is transitional to a complicated pedocomplex (up to $2 \mathrm{~m}$ thick). On the basis of the investigation of the Pryluky pedocomplex in sedimentation traps, it is possible to identify up to 6 phases of soil formation: $\mathbf{p l}_{1 \mathrm{~b} 1}, \mathbf{p l}_{1 \mathrm{~b} 2}, \mathbf{p l}_{1 \mathrm{c}}, \mathbf{p l}_{3 \mathrm{a}}, \mathbf{p l}_{3 \mathrm{bl}}$, $\mathbf{p l}_{3 \mathrm{~b} 2}$

2. In most of the studied sections, the Prylyky pedocomplex has a sandy loam composition, due to the inheritance of parent lithologies. The main erosion breaks are situated at the lower boundary of the pedocomplex and on the top of the $\mathbf{p l}_{1 \mathrm{~b} 2}$ soil.

3. During the $\mathbf{p l}_{1 \mathrm{bl}}$ early optimum, forest soils were formed, with varying degrees of podzolization, depending on the variations in parent materials. On sands Podzols were formed, on loess-like sandy loam Albeluvisols and Cryptopodzolics were formed, and on the sandy loam soils of the Kaydaky unit albic Luvisols were formed.

4. During the $\mathbf{p l}_{1 b 2}$ late optimum, there was aridification, which led to the activation of humus accumulation under mesophytic steppe, indicated by high humus content (up to $1 \%$ ), the dominance of dark mull humus and complex microaggregation. The spatial difference between soils is weak, but depending on the palaeorelief and grain-size composition of the parent material soils, there is variety: on the sandy loams Cryptododzol was formed; on the sandy loams and loams luvic Chernozem and Chernozem-like soils were formed; on the silty loams chernic Chernozem was formed; and on the alluvial sands mollic Fluvisol was formed.

5. During the $\mathbf{p l}_{1 \mathrm{c}}$ phase, Umbrisols and cambic Luvisols were formed. The former have relatively a high content of humus and complex microaggregation. The latter are characterized by increasing clay content 
downwards in the profile. The origin of light-brown spots is not still clear of obscure origin.

6. Soils of the $\mathbf{p l}_{3}$ subunit are often denuded, and strongly disturbed by solifluction and cryogenic pedometamorphism. In relief depressions, subunit $\mathbf{p l}_{3}$ is represented by pedosediment of Luvisols. During $\mathbf{p l}_{3}$ times a trend in the evolution of pedogenesis can be seen; $\mathbf{p l}_{3 \mathrm{a}}$ - mollic Cambisol; $\mathbf{p l}_{3 \mathrm{~b} 1}$ - Luvisol and luvic Cambisol; $\mathbf{p l}_{3 \mathrm{~b} 2}$ - luvic and mollic Cambisols.

\section{References}

Artyushenko A.T., Arap R.Ya., Bezusko L.G., 1982. Istoriya rastitelnosti zapadnyih oblastey Ukrainyi $\mathrm{v}$ chetvertichnom periode [Vegetation history of the western regions of Ukraine during the Quaternary]. Kiev, Naukova Dumka (in Russian).

Bezusko L.H., Mosiakin S.L., Bezusko A.H., 2011. Zakonomirnosti ta tendentsii rozvytku roslynnoho pokryvu Ukrainy $\mathrm{u}$ piznomu pleistotseni ta holotseni [Regularities and trends of the Ukrainian vegetation cover during the Late Pleistocene and the Holocene]. Alterpres, Kyiv (in Ukrainian)

BoguckyiA., 1986. Antropogenovye pokrovnye otlozheniya Volyno-Podolii [Anthropogenic surface deposits of the Volino-Podolia]. Anthropogenovy vidklady Ukrainy. Naukova Dumka, Kyiv, 121-132 (in Russian).

Bogutskyi A., Voloshyn P., 2008. Inzhereno-heolohichna kharakterystyka porid opornoho lesovoho rozrizu Rivne (Volynska vysochyna) [Engineeringgeological characteristics of the deposits at the key loess profile Rivne (Volyn Upland)]. Visnyk Lviv univ. Ser. Geogr., 35, 7-15 (in Ukrainian).

Bogutskyi A., Voloshyn P., 2010. Inzhereno-heolohichna kharakterystyka porid lesovo-hruntovoi serii opornoho rozrizu Zdolbuniv (Volynska vysochyna) [Engineering-geological description of the rocks of loess-soil series at the Zdolbuniv key profile (the Volyn upland). Visnyk Lviv univ. Ser. Geogr., 38, 21-27 (in Ukrainian).

Bogutskyi A., Voloshyn P., 2011. Inzhenerno-heolohichna kharakterystyka porid lesovo-gruntovoi serii opornoho rozrizu Dubno (Tarkaniv), Volynska vysochyna [Engineering-geological characteristics of the rocks of loess-soil series at the key profile Dubno (Tarakaniv), the Volyn Upland]. Visnyk Lviv univ. Ser. Geogr., 39, 28-34 (in Ukrainian).

Bogutskyi A., Lanczont M., Tomenyuk O., Sytnyk O., 2012. Deliuvialno-solifliuktsiini protsesy y problemy perevidkladennia i datuvannia paleolitychnykh kultur [Colluvial-solifluctional processes and problems of redeposition and dating of Paleolithic cultural horizons]. Materialy doslidzhen' z archeologii Karpat i Volyni, 16, 5564 (in Ukrainian).

Bolikhovskaya N.S., 1995. Evolyutsiya lessovopochvennoy formatsii Severnoy Evrazii [Evolution of the loess-soil formation of Northern Eurasia]. MGU, Moskow (in Russian).

Doroshkevych S.P. 2018. Pryroda serednoho Pobuzhzhia u pleistotseni. Za danymy vyvchennia vykopnykh gruntiv [The nature of the Middle Pobuzhzhia in the Pleistocene. According to the study of fossil soils]. Naukova Dumka, Kyiv (in Ukrainian).

Gagarina E.I., 2004. Mikromorfologicheskiy metod issledovaniya pochv [Micromorphological method of soils studies]. Sankt-Peterburg (in Russian).

Gerasimenko N.P., 2004. Rozvytok zonalnykh landshaftiv chetvertynnoho periodu na terytorii Ukrainy [The development of zonal landscapes of the Quaternary period in the territory of Ukraine]. Avtoref. of Doctor of Sciences' thesis in Geography, Institute of Geography of NASU, Kyiv (in Ukrainian).

Gerasimenko N., 2006. Upper Pleistocene loess-palaeosol and vegetational successions in the Middle Dnieper Area, Ukraine. Quaternary International, $149,55-66$.

Gerasimenko N.P., 2010. Osnovy paleoheohrafii chetvertynnoho period [Bases of the Quaternary Palaeogeography]. Obrii, Kyiv (in Ukrainian).

Gerasimova M.I., Gubin S.V., Shoba S.A., 1992. Mikromorfologiya pochv prirodnyh zon SSSR [Micromorphological features of the USSR zonal soils]. Pushchino Centre of Science, Pushchino (in Russian).

Haesaerts, P., Damblon, F., Gerasimenko, N., Spagna, P., Pirson., 2016. The Late Pleistocenen loesspalaeosol sequence of Middle Belgium. Quaternary International, 411, 25-43.

Karmazinenko S.P., 2010. Mikromorfolohichni doslidzhennia vykopnykh i suchasnykh gruntiv Ukrainy [Micromorphological studies of buried and modern soils of Ukraine]. Naukova Dumka, Kyiv (in Ukrainian)

Komar M.S., Prylypko S.K., 2009. Polozheniye prilukskogo termokhrona i ego analogov v stratigraficheskikh skhemakh Evropy [The position of the Pryluki thermochron and its analogues in the stratigraphic schemes of Europe]. Collection of scientific works of the IGS NAS of Ukraine, 2, 190-193 (in Russian)

Lanczont M, Bogutskyj A., 2007. High-resolution terrestrial archive of climatic oscillations during Oxygen Isotope Stages 5-2 in the loess-palaeosol sequence at Kolodiiv (East Carpathian Fore land, Ukraine). Geological Quaterly, 51 (2), 105-126.

Lindner L., Bogutsky A., Gozhik P., Marciniak B., Marks L., Lanczont M., Wojtanowicz J., 2002. Correlation of main climatic glacial-interglacial and loess-paleosol cycles in the Pleistocene of Poland and Ukraine. Acta Geologica Polonica, 52 (4), 459-469.

Lindner L., Gozhik P., Marks L., Lanczont M., Wojtanowicz J., 2006. Correlation of Pleistocene deposits in the 
area between the Baltic and Black Sea, Central Europe. Geological Quarterly, 50 (1) - p. $195-$ 210.

Matviishyna Zh. N., 1982. Mikromorfologiya pleystotsenovykh pochv Ukrainy [Micromorphological of the Pleistocene soils of Ukraine]. Naukova Dumka, Kyiv (in Russian).

Matviishina V.I. Zh., N., Gerasimenko N.P., Perederiy et al., 2010. Prostorovo-chasova korelyatsia paleogeografichnych umov chetvertynnogo periody na teritorii Ukrainy [Spacial-temporal correlation of paleogeographical events of Quaternary in the area of Ukraine].Naukova dumka, Kyiv (in Ukrainian).

Morozova T.D., 1981. Razvitie pochvennogo pokrova Evropy $\mathrm{V}$ pozdnem pleystotsene. [The development of the soil cover of Europe in the Late Pleistocene].Nauka, Moskow (in Russian).

Nechaev V.P., 1983. Paleokriogennye protsessy na teritorii Volyno-Podolskoy vozvyishennosti v verhnem pleystotsene [Palaeocryogenic processes in the Volyn-Podolsk Upland during the Upper Pleistocene]. Abstract. Moscow, 19. (In Russian).

Parfeneva E.I., Yarilova E.A., 1977. Rukovodstvo k mikromorfologicheskim issledovaniyam $\mathrm{v}$ pochvovedenii [Guide to micromorphological studies in the Soil Science]. Nauka, Moskva (in Russian).

Rousseau D.D., Gerasimenko N., Matviishina Zh., Kukla G., 2001. Late Pleistocene Environments of the Central Ukraine. Quaternary Research, 56, 349356.
Sirenko N.A., Turlo S.I., 1986. Razvitiye pochv i rastitelnosti Ukrainy $\mathrm{v}$ pliotsene i pleystotsene [Development of soils and vegetation of Ukraine during the Pliocene and Pleistocene]. Naukova Dumka, Kyiv (in Russian).

Sycheva S.A., Grigoryeva T.G., Pushkina P.R., 2017. Stratigrafiya rannevaldayskogo interval vnelednikovoy oblasti russkoy ravniny (MIS 5d4) [Stratigraphy of the Early Valdai (MIS 5d-4) deposits in non-glaciated areas of the Russian plain]. Byulleten kommissii po izucheniyu chetvertichnogo perioda, 75, 60-80 (in Russian).

Tsatskin A.I., 1980. Paleopedologichekie rekonstruktsii dlya pozdnego pleystotsena yugo-zapada Russkoy ravninyi [Paleopedological reconstructions for the Late Pleistocene of the southwest of the Russian Plain]. Abstract. Moscow (In Russian).

Veklich M.F., 1982. Paleoetapnost i stratotipy pochvennykh formatsiy Ukrainy verkhnego kaynozoya [Paleostages and stratotypes of the soil formations of Ukraine in the Upper Cenozoic]. Naukova Dumka, Kyiv (in Russian).

Veklych M.F., Sirenko N.O., Dubniak V.O., Melnychuk I.V., Maiska Zh.M., Paryshkura S.I., 1973. Rozvytok hruntiv Ukrainy u piznomu kainozoi [Development of soils of Ukraine duirng the Late Cenozoic]. Naukova Dumka, Kyiv (in Ukrainian).

Veklitch M.F, Matviishina Zh.N., Medvedev V.V., Sirenko N.A, Fedorov K.N., 1979. Metodika paleopedologicheskih issledovaniy [Methodology of palaeopedological studies]. Naukova Dumka, Kiev (in Russian). 